\title{
10 Years Experience with Bacterial Screening of Platelet Concentrates in the Netherlands
}

\author{
Dirk de Korte \\ Sanquin Blood Bank Department of Product and Process Development and Sanquin Research, Department of Blood Cell Research, \\ Amsterdam, the Netherlands
}

\section{Keywords}

Bacterial contamination - Buffy coat .

Platelet concentrates · Platelet storage

\section{Summary}

Background: Contamination of platelets with bacteria is the major microbiological risk of blood transfusion. Screening for bacterial contamination can reduce the frequency of bacterial transmission considerably. In the present paper, the results of 10-year screening in the Netherlands are described. Methods: All platelet concentrates were cultured with the BacT/Alert culturing system with large volume $(7.5 \mathrm{ml})$ cultures in either an aerobic or an anaerobic bottle. Products were released on a 'negative-to-date' basis. Results: After introduction of the diversion of the first milliliters of collected blood, the number of positive screening cultures decreased significantly from $0.85 \%$ to $0.37 \%$. The frequency of transfusion-transmitted bacterial infections by platelet concentrates is currently less than 1 per 2 years in the Netherlands. Conclusion: Over a period of 10 years the bacterial screening system for platelet concentrates proved to result in a safe system with respect to microbiological infection as a result of platelet transfusions.

\section{Introduction}

Contamination of platelets with bacteria is the major microbiological risk of blood transfusion, although screening for bacterial contamination can reduce the frequency of bacte-

\section{Schlüsselwörter}

Bakterielle Kontamination - Buffy Coat .

Thrombozytenkonzentrate · Thrombozytenlagerung

\section{Zusamenfassung}

Hintergrund: Die Kontamination von Thrombozyten mit Bakterien ist größte mikrobiologische Risiko bei der Bluttransfusion. Das Screening auf eine bakterielle Kontamination kann die Häufigkeit von bakteriellen Übertragungen deutlich reduzieren. Die Ergebnisse eines 10-JahresScreenings in den Niederlanden werden im Folgenden vorgestellt. Methoden: Alle Thrombozytenkonzentrate wurden mit dem BacT/Alert-Kultursystem in großvolumigen $(7,5 \mathrm{ml})$ Kulturen entweder in einer aeroben oder in einer anaeroben Flasche kultiviert. Die Produkte wurden auf "Negative-to-date»-Basis freigegeben. Ergebnisse: Durch die Etablierung der Abzweigung der ersten Milliliter des frisch entnommenen Bluts konnte die Zahl an positiven Screening-Kulturen signifikant von 0,85\% auf $0,37 \%$ gesenkt werden. Die Häufigkeit von durch Transfusion übertragenen bakteriellen Infektionen ist sehr gering in den Niederlanden. Schlussfolgerung: Über einen Zeitraum von 10 Jahren erwies sich das bakterielle Screening-System für Thrombozytenkonzentrate als ein sicheres System in Hinblick auf mikrobiologische Infektionen infolge von Thrombozytentransfusionen.

rial transmission considerably. Especially platelet concentrates (PCs) are at risk, because their storage conditions at room temperature and under constant agitation with sufficient nutrients support bacterial growth. In the Netherlands, $>95 \%$ of PCs are prepared from pools of buffy coats from

\begin{tabular}{ll}
\hline KARGER & @ 2011 S. Karger GmbH, Freiburg \\
Fax +497614520714 & Accessible online at: \\
Information@Karger.de & www.karger.com/tmh \\
www.karger.com &
\end{tabular}

Dirk de Korte

Sanquin Blood Bank, Department of Product and Process Development and

Sanquin Research, Department of Blood Cell Research

Plesmanlaan 125, 1066 CX Amsterdam, the Netherlands

d.dekorte@sanquin.nl 
5 different donors, and only a minority is collected via apheresis. The buffy coats are produced from overnight hold whole blood $\left(14-20 \mathrm{~h}\right.$ at $\left.20-24^{\circ} \mathrm{C}\right)$. Since 2001 all PCs are tested for bacterial contamination by culturing in the BacT/Alert (bioMérieux, Nürtingen, Germany) system (aerobic and anaerobic bottle, $7.5 \mathrm{ml}$ each, inoculated within $2 \mathrm{~h}$ after production) for 7 days. The PCs are released on a 'negative-to-date' result, which means that at the moment of issuing the culture bottles of the PCs are negative for bacterial growth; thus the PCs can be transfused. However, the culturing continues for up to 7 days, and during this period the culture bottles can still become positive for bacterial growth. When a PC from platelet buffy coats is flagged positive for bacterial growth, the 5 related red blood cell concentrates (RBCs) are also cultured for bacterial growth. Due to the short shelf life, it was decided to perform no retesting on PCs, but to destroy the product. However, RBCs are released again if negative during the 7-day culture. This article describes the results obtained during 10 years of $100 \%$ bacterial screening for PCs in the Netherlands.

\section{Rate of Initial Positive Cultures in the Screening}

In the first years after the start in 2001, an initial positive rate of $0.95 \%$ was found for whole blood-derived PCs, which was only minimally decreased to $0.85 \%$ in 2002 by the introduction of a double swab disinfection method for the phlebotomy place. For apheresis PCs the initial positive rate was considerable lower, with about $0.3 \%$. A study using whole blood and diversion of the first $10 \mathrm{ml}$ of blood showed that a significant reduction of bacterial contamination was possible [1]. Therefore, this approach was tested for the production of whole blood-derived PCs. A pilot project using an adapted blood bag system allowing for diversion of the first 2-20 $\mathrm{ml}$ of whole blood showed an about $50 \%$ reduction of initially positive cultures. Thus, it was decided in 2004 to introduce the blood bag system with a deviation bag (to be used to fill test tubes) as standard in the Netherlands. By this and in combination with the double swab disinfection method, the rate for initially positive whole blood-derived PCs could be decreased from $0.85 \%$ to $0.37 \%$ [2]. After the introduction of the deviation bag the percentage of initially positive cultures ranged around $0.4 \%$ for both whole blood-derived PCs and apheresis PCs. For apheresis PCs diversion of the first blood volume was used over the whole period from 2001 till now. Over the years, the percentage confirmed positive (i.e., a microorganism could be isolated from the positive culture bottle) showed some variation, but was relatively constant. From about $80 \%$ of initially positively flagged bottles a microorganism could be isolated and identified. The frequency of a false-positive result (which means, no microorganisms could be cultured from the bottle flagged positive) was about two-fold higher for the anaerobic bottles.

\section{‘Negative to Date’ in Clinical Practice}

Due to the principle of 'negative to date', PCs which are already transfused may have a positive culture result afterwards. If this was the case, the hospital was contacted, and it was explained that there is a chance that the unit transfused had been bacterially contaminated. It was also explained that the growth in the culture was normally ahead of the growth in the PC from which the sample was taken and that a bacterial transmission by the PC would be rare. This message was very well understood and accepted by the clinicians. During the years in which $100 \%$ screening was applied, the number of units released as 'negative to date' with a positive culture after being transfused decreased substantially by introduction of the deviation bag. In the first years we had about 230 units/ year being released as 'negative to date' but with a subsequent positive culture after transfusion. After introduction of the deviation bag this decreased to a mean of 110 units/year. Over a period of 4 years (2006-2009), we actively looked back to 435 patient records of these transfusions and found only 3 cases with a reported transfusion reaction. For these cases in which a transfusion reaction was reported the imputability of being related to the transfusion of a contaminated PC was unlikely (as reported for the year's 2006 and 2007 [3]). Therefore, we concluded that the Dutch screening system in combination with release as 'negative to date' is a safe system.

\section{Transfusion-Transmitted Bacterial Infections}

Since 2003 we have a national hemovigilance system in the Netherlands with reporting on a voluntary basis. After the start-up years, since 2005 more than $95 \%$ of the hospitals are participating in this system, which is called Transfusion Reactions In Patients (TRIP). Unfortunately, no data are available on the number of transfusion-transmitted bacterial infections (TTBI) before TRIP started. In the initial years of TRIP when bacterial screening was just implemented, some severe TTBI linked to PCs released as 'negative to date' were reported. Also upon subsequent culture, the cultures of these PCs remained negative. This would suggest false-negatives missed in the screening. However, it could not be excluded that the bacteria were introduced to the products after initial sampling for the BacT/Alert cultures. In the years since the introduction of deviation for the first milliliters of blood collected, only a vanishingly small number of severe TTBI related to PCs was reported. During the years 2007-2009 only 2 cases of TTBI linked to PCs with negative screening result were reported with certain (proven) or probable (very likely) imputability and serious or higher severity (TRIP reports, see $w w w . t r i p n e t . n l)$. 


\section{Shelf Life of Platelet Concentrates in the Netherlands}

After the reduction of shelf life for PCs from 7 to 5 days in the USA (Food and Drug Administration, Transcript of 32nd Meeting of the Blood Products Advisory Committee, May 9, 1991) based on suspicion of increased TTBI by longer stored PCs, also in the Netherlands the shelf life was reduced to 5 days. Because this reduction in shelf life was not based on doubt about the quality of the platelets, it was decided in 2002 to increase the shelf life of PCs again to 7 days after the successful introduction of $100 \%$ screening of PCs in the Netherlands. This was supported by the results of a clinical study by Dijkstra et al. [4], showing that the corrected count increments (CCIs) after 1 and $24 \mathrm{~h}$ PCs stored for 7 days were comparable to those of PCs stored for 5 days. Based on in vitro quality measurements, it was already known for a long time [5-7] that with the improved containers for platelets, storage for up to 7 days should be no problem either for PCs derived from pooled buffy coats or for those collected by apheresis.

\section{Final Thoughts}

One of the weak points of bacterial screening is the fact that usually the PCs have a low initial contamination with bacteria. This is reflected by the fact that in our screening more than $90 \%$ of cultures with a microorganism that is able to grow in both the aerobic and the anaerobic bottle was only positive in one of the two bottles. In the Netherlands we use a very sensitive system, with a high inoculation volume (mean $7.5 \mathrm{ml} /$ bottle) and two bottles, resulting in a high initial positive rate compared to other countries. Nevertheless, units with an initial very low contamination can be missed, although not in all cases this low contamination will survive in the PC during storage and lead to a severely contaminated unit during storage.
However, based on reported cases [8-10], it is clear that falsenegatives occur, but no hard data on the frequency in regular screening could be derived from these reports. Recently, several studies reported on the frequency of false-negatives, one for apheresis PCs [11] and two for buffy coat-derived PCs [12, 13 ], being around $0.1 \%$. In addition, a study on bacterial contamination of outdated PCs was finished in the Netherlands, showing similar results [14]. In combination with the fact that in the Netherlands hardly any TTBI due to PCs were reported over the last years, it was decided that there was no need for a rapid detection system to be used as additional release test for units after longer storage than 4 or 5 days.

Introduction of pathogen reduction technology for PCs has been under discussion in the Netherlands for a long time, as in theory this approach would be the ideal solution to prevent all kind of transfusion transmittable infections. However, due to the negative effects on platelet quality and/or quantity, this approach is not considered to be implemented soon in the Netherlands. The Dutch Health Council stated in their 2004 advice to the government about pathogen reduction technologies that 'the benefit of risk reduction is not justifying the introduction of new risks by increased transfusion frequency'.

Recently, the results of a Dutch trial with Intercept PCs (treated with Amotosalen and UVA light; Cerus Corporation, Concord, CA, USA) were reported by Kerkhoffs et al. [15], showing lower clinical efficacy for the Intercept arm with respect to CCI and bleeding events. Currently, in the Netherlands the so-called PREPAReS study is running, in which Mirasol PCs (treated with Riboflavin and UVB light; Caridian BCT, Denver, CO, USA) derived from whole blood are studied.

\section{Disclosure Statement}

The author declared no conflicts of interest.

\section{References}

1 de Korte D, Marcelis JH, Verhoeven AJ, Soeterboek AM: Diversion of first blood volume results in a reduction of bacterial contamination for whole-blood collections. Vox Sang 2002;83:13-16.

2 de Korte D, Curvers J, de Kort W, Hoekstra T, van der Poel C, Beckers EAM, Marcelis JH: Effects of skin disinfection method, deviation bag and bacterial screening on clinical safety of platelet transfusions in the Netherlands. Transfusion 2006;46:476-485.

$>$ Koopman MM, van't Ende E, Lieshout-Krikke R, Marcelis J, Smid WM, de Korte D: Bacterial screening of platelet concentrates: results of 2 years active surveillance of transfused positive cultured units released as negative to date. Vox Sang 2009;97: 355-357.

4 Dijkstra-Tiekstra MJ, Pietersz RNI, Hendriks EC, Reesink HW, Huijgens PC: In vivo PLT increments after transfusions of WBC-reduced PLT concentrates stored for up to 7 days. Transfusion 2004;44:330-336.
5 de Wildt-Eggen J, Schrijver JG, Bouter-Valk HJ, Fijnheer R, Bins M, van Prooijen HC: Improvement of platelet storage conditions by using new polyolefin containers. Transfusion 1997;37:476-481.

-6 Kostelijk EH, Fijnheer R, Nieuwenhuis HK, Gouwerok CWN, de Korte D: Soluble p-selectin as parameter for platelet activation. Thromb Haemost 1996;76:1086-1089.

7 Boomgaard MN, Joustra-Dijkhuis AM, Gouwerok CWN, Steneker I, Reesink HW, Loos JA, Pietersz RNI, de Korte D: In vitro evaluation of platelet concentrates, prepared from pooled buffy coats, stored for 8 days after filtration. Transfusion 1994;34:311-316.

8 Te Boekhorst TAW, Beckers EAM, Vos M, Vermeij H, van Rhenen DJ: Clinical significance of bacteriologic screening in platelet concentrates. Transfusion 2005;45:514-519.
9 Lessa F, Leparc GF, Benson K, Sanderson R, Van Beneden CA, Shewmaker PL, Jensen B, Arduino MJ, Kuehnert MJ: Fatal group C streptococcal infection due to transfusion of a bacterially contaminated pooled platelet unit despite routine bacterial culture screening. Transfusion 2008;48:2177-2183.

10 Ramirez-Arcos S, Chin Yee I, Hume H, Fearon M, Goldman M, Eckert K, Martinic I, Peters G, Kovach D, Richardson SE: Fatal septic shock associated with transfusion-transmitted Serratia marcescens. Transfusion 2006;46:679-681.

11 Dumont LJ, Kleinman S, Murphy JR, Lippincott R, Schuyler R, Houghton J, Metzel P: Screening of single-donor apheresis platelets for bacterial contamination: the PASSPORT study results. Transfusion 2010;50:589-599. 
12 Murphy WG, Foley M, Doherty C, Tierney G, Kinsella A, Salami A, Cadden E, Coakley P: Screening platelet concentrates for bacterial contamination: low numbers of bacteria and slow growth in contaminated units mandate an alternative approach to product safety. Vox Sang 2008;95:13-19.
13 Pearce S, Rowe GP, Field SP: Screening of platelets for bacterial contamination at the Welsh Blood Service. Transfus Med 2011;21:25-32.

14 Karssing W, Wildt-Eggen J, van Zeelst J, Geurts P, Koolen JT, Rood IG, de Korte D: Frequency of false-negative cultures in screening of platelet concentrates for bacterial contamination. Transfusion 2010;50(suppl):31A.
15 Kerkhoffs JL, van Putten WL, Novotny VM, Te Boekhorst PA, Schipperus MR, Zwaginga JJ, van Pampus LC, de Greef GE, Luten M, Huijgens PC, et al: Clinical effectiveness of leucoreduced, pooled donor platelet concentrates, stored in plasma or additive solution with and without pathogen reduction. Br J Haematol 2010;150:209-217. 